\title{
Aboriginal stone huts along the Georgina River, southwest Queensland
}

\author{
Lynley A. Wallis ${ }^{\mathrm{a}}$, Iain Davidson ${ }^{\mathrm{b}}$, Heather Burke ${ }^{\mathrm{c}}$, Scott Mitchell ${ }^{\mathrm{d}}$, Bryce Barker ${ }^{\mathrm{e}}$, Elizabeth \\ Hatte $^{\mathrm{f}}$, Noelene Cole $\mathrm{g}$ and Kelsey M. Lowe

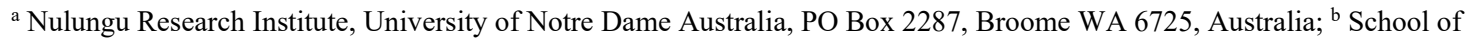 \\ Humanities, University of New England, Armidale NSW 2351, Australia; ${ }^{\mathrm{c}}$ Department of Archaeology, Flinders University, \\ GPO Box 2100, Adelaide SA 5001, Australia; ' Western Australian Museum, Locked Bag 49, Welshpool DC WA 6986, \\ Australia; ${ }^{\mathrm{e}}$ School of Arts and Communication, University of Southern Queensland, Toowoomba QLD 4350, Australia; ${ }^{\mathrm{f}}$ \\ Northern Archaeology Consultancies Pty Ltd, 88 Mcllwraith Street, South Townsville QLD 4810, Australia; ${ }^{\mathrm{g}}$ College of \\ Arts, Society and Education, James Cook University, PO Box 6811, Cairns QLD 4870, Australia
}

* Corresponding author Lynley.Wallis@nd.edu.au

\begin{abstract}
This paper reports on the recording of previously unpublished Aboriginal stone hut structures in southwestern Queensland. Located along a tributary of the Georgina River, these 17 structures are typical of the region, being generally circular in plan view, with an average diameter of $5 \mathrm{~m}$ and a $1 \mathrm{~m}$-wide opening consistently positioned to afford protection from prevailing winds. Evidence suggests these structures were roofed with vegetation and, while they pre-date the contact period, appear also to have been used into at least the late 1800s. Artefacts associated with them include stone flakes, cores and edge-ground axe fragments, freshwater mussel shells, rifle cartridge cases, fragments of glass, and metal objects. A comparison of these stone hut structures is made with similar features from elsewhere in Australia, demonstrating that there was a widespread but consistent use of stone for construction. This short report contributes to an increasing awareness of, and literature about, built structures in traditional Aboriginal societies.
\end{abstract}

\section{Introduction}

There is growing awareness of Aboriginal peoples' use of built stone structures in the pre-contact period around Australia (e.g. Builth 2002; Clarke 1991, 1994; Coutts et al. 1978; Lewis 1988; Memmott 2012; Mulvaney 1993; O'Connor 1987, 1999; O’Connor et al. 2007; Wallis and Matthews 2016). This is contrary to some common misconceptions about Aboriginal lifeways. Although not intended as a 'definitive guide to Australian Aboriginal ethnoarchitecture', Memmott (2007:xiii) provided a continentalwide overview of Indigenous built structures in Australia, concluding that:

The intermittent reporting of individual ethnographic examples in the anthropological and archaeological literature in the last century generates sufficient material to mount an argument that there was widespread use of stone structures in Aboriginal Australia, not only for shelter and house walls, but even for roof cladding in one case.

Located in southwest Queensland, the stone hut structures that we describe here were first recorded by Rowlands and Rowlands (1978). Some were subsequently recorded in detail by Davidson et al. (1989) as part of a wider project nominating sites to the then Register of the National Estate, but details were never published. Memmott (2007) included mention of them in his Australia-wide review, citing the original Davidson et al. (1989) report without expanding upon it. As such, they are little known; this report redresses that lack.

\section{The Study Area}

The study site is located on Marion Downs Station, about $60 \mathrm{~km}$ southwest of Boulia in the traditional lands of the PittaPitta people (Figure 1). Above the cracking clays and alluvial sediments associated with the channels of the Georgina River, the landscape is dominated by a stony gibber of siliceous rock derived from erosion of the Tertiary Marion Formation (Wilson 1990:5). These rounded gibber rocks, coated with iron oxide, are the source of the building material for the stone hut structures.

Data collected at Marion Downs (weather station 38014) over the past century indicates mean annual rainfall in the study area is just over $200 \mathrm{~mm}$, most of which falls during the summer months. In drought years less than $40 \mathrm{~mm}$ has been recorded, while in wet years as much as $680 \mathrm{~mm}$ has fallen. The mean monthly annual temperature, based on data collected at Boulia airport (weather station 38003), is a low of $22.9^{\circ} \mathrm{C}$ during July and a high of $38.6^{\circ} \mathrm{C}$ in December (BoM 2016). The prevailing wind direction for most of the year is from the south and southwest (BoM 2016).

\section{Methods}

The original site recording was made in 1989 , with a return visit in 2016 to reassess the condition of the site and to confirm aspects of the original recording. During the 1989 fieldwork a general site plan was drawn using a theodolite. Detailed plans were drawn of two typical structures using a baseline-offset technique, with all stones larger than $10 \mathrm{~cm}$ drawn individually to scale. Non-systematic pedestrian transects were walked across the site in both 1989 and 2016 to ascertain the range of artefacts represented on the ground surface.

\section{Results}

The stone structures are located approximately $300 \mathrm{~m}$ west of the Georgina River and $100 \mathrm{~m}$ south and west of a meandering unnamed small tributary on a gentle incline of a low, boulderstrewn hill. The huts are found across an area measuring $125 \mathrm{~m}$ 

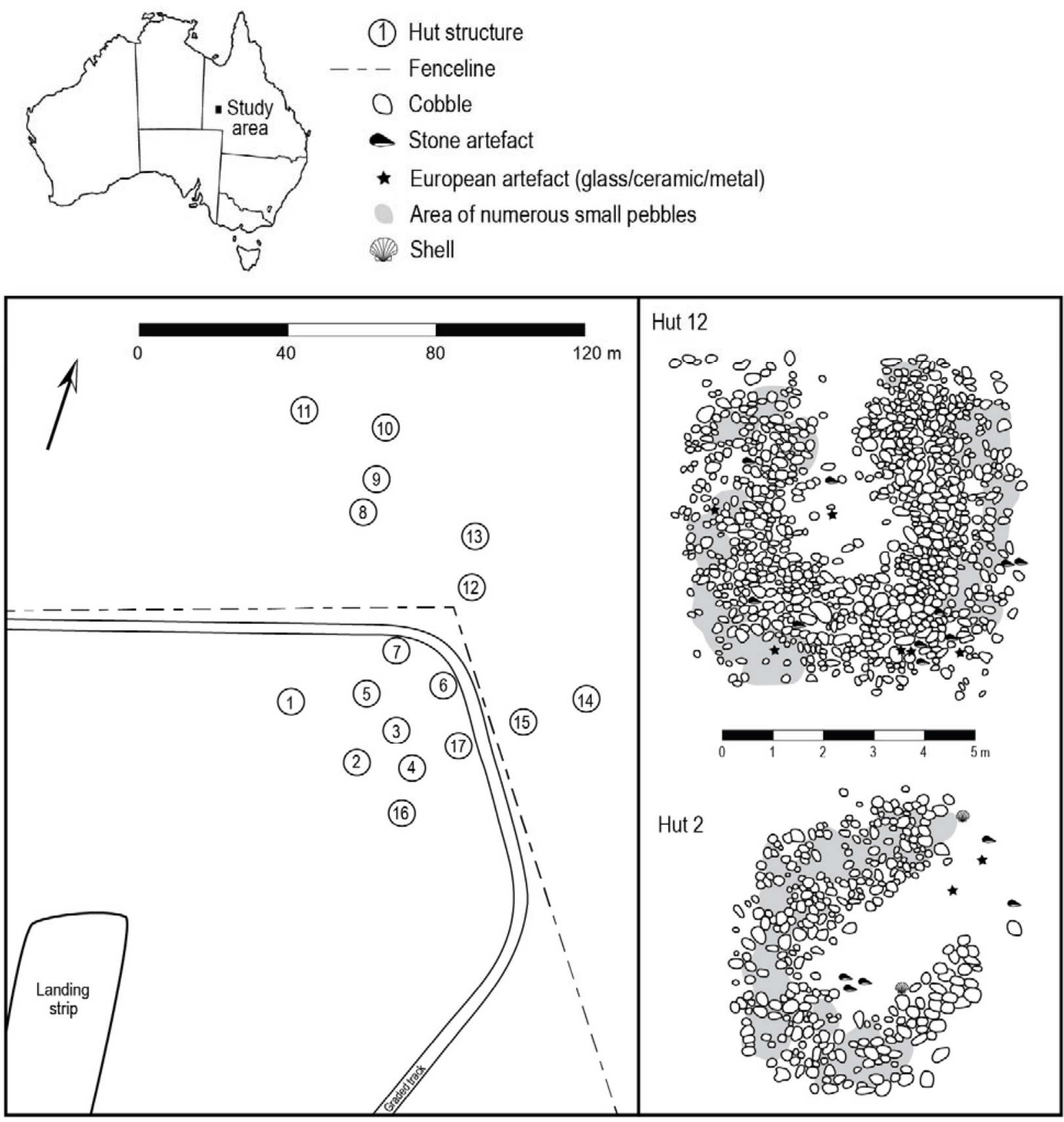

Figure 1. The study area, including scale drawings of two of the Marion Downs huts.

$\mathrm{x} 110 \mathrm{~m}$, positioned at the northern end of the station's airstrip (Figure 1) (Davidson et al. 1989:17). There are 15 circular and two somewhat more rectangular structures, consisting of low stone walls with an average diameter of $5 \mathrm{~m}$, each of which has a c.1m-wide opening (Figures 1-2). The openings are quite regular in orientation, ranging between $330^{\circ}$ and $30^{\circ}$ (i.e. north-northwest, north, north-northeast), opposite to the prevailing wind direction (BoM 2016). The average internal area of the huts is $7.1 \mathrm{~m}^{2}$. Although the walls have often collapsed across a width of up to $1 \mathrm{~m}$, in some instances they are still up to $45 \mathrm{~cm}$ in height (Figure 2). They are constructed of locally available, rounded silcrete cobbles and boulders from the gibber, which on average are between $20 \mathrm{~cm}$ and $30 \mathrm{~cm}$ in diameter. The boulders can be easily moved by a single person without assistance. The rock-free internal floor space contains soft sediment. These form one of several groups of similar stone hut structures known on the property. One group at Hilary Creek was visited in 1989 but these were neither mapped nor archaeologically recorded. The presence in 1989 of collapsed gidgee (Acacia cambagei) boughs over some of the Hilary Creek stone hut structures strongly suggests that they originally had a dome-shaped superstructure of heavy curved boughs (Figure 3). Only one of the huts at the airstrip site had evidence of a bough super-structure remaining. This roof was likely clad with hummock or spinifex grasses, possibly with a coating of sand, mud or clay, given the absence of an obvious source of tree bark (cf. Memmott 2007:13). 


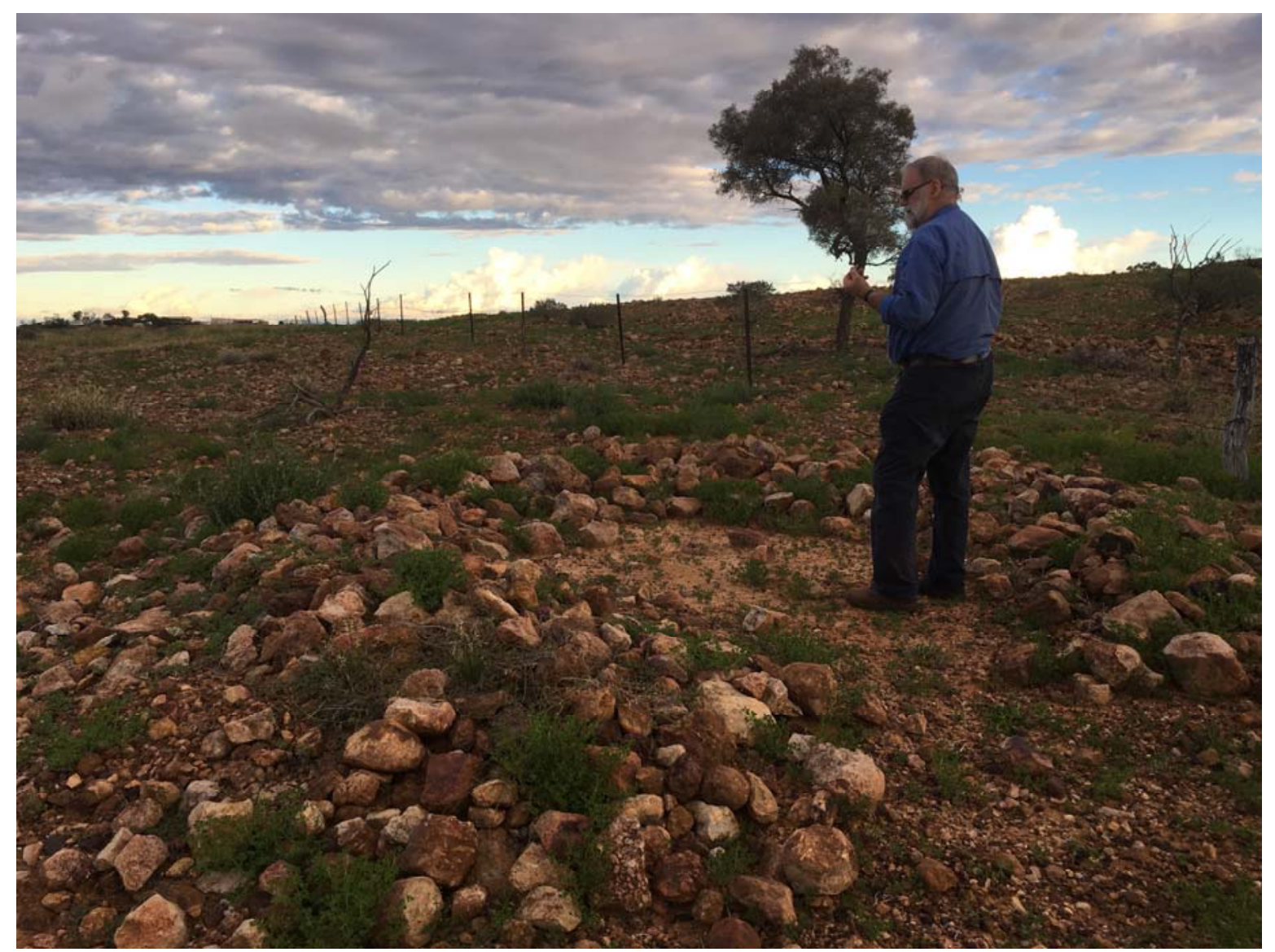

Figure 2. Iain Davidson inspecting one of the Marion Downs huts in 2016 (Photograph: Lynley Wallis).

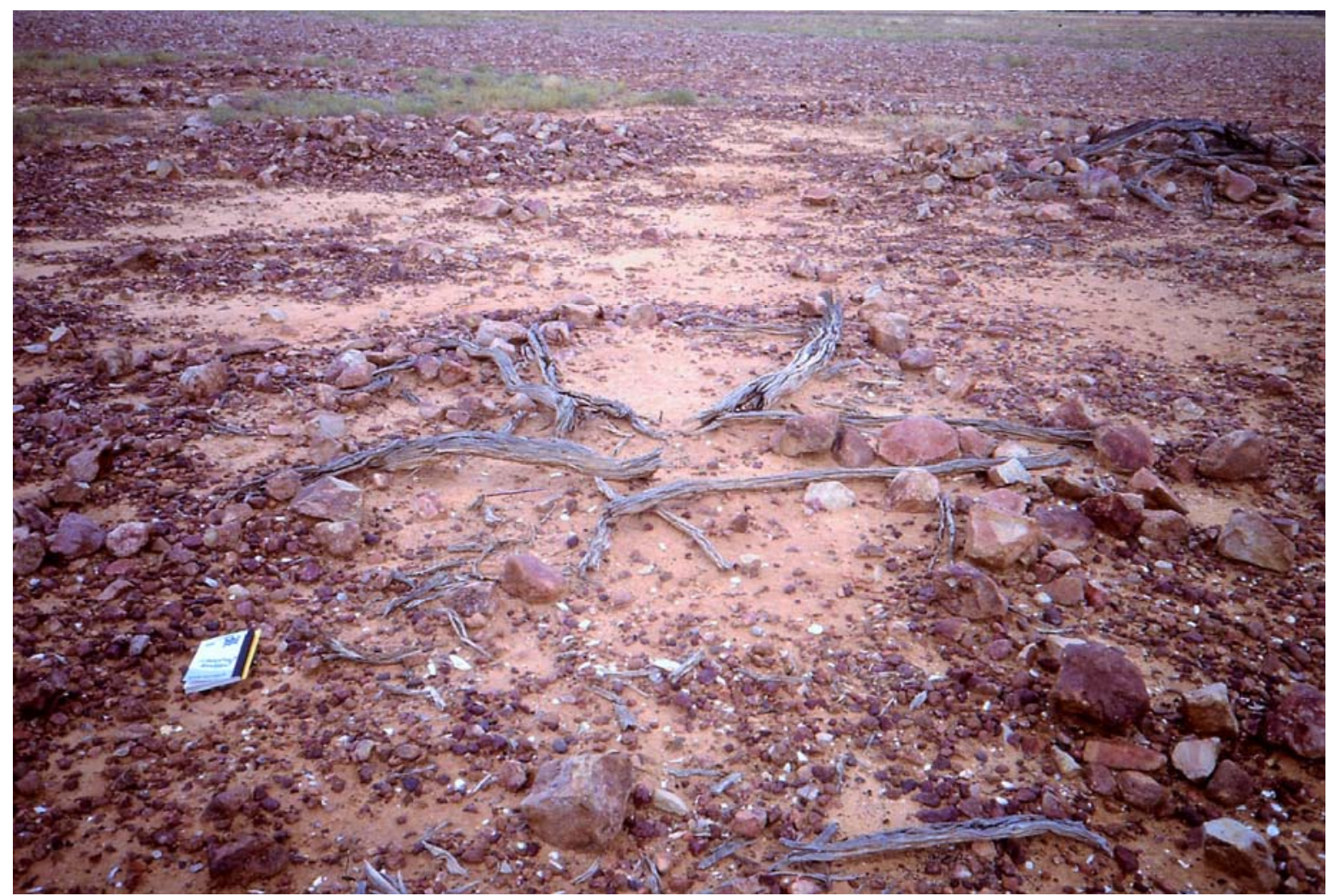

Figure 3. Collapsed roofing structure on a hut on Hilary Creek, Marion Downs (foreground), with a second collapsed structure in the right background, taken in 1989 (Photograph: Iain Davidson). 
The condition of the stone hut structures in 1989 was recorded as being:

generally good, but deteriorating due to natural weathering. A track had been graded through the middle of the group near the fence, but there is no clear indication that any huts were destroyed by this. It has the effect that traffic mostly goes along that now, thus affording some protection. Some damage to the site by cattle and horses is possible, but unlikely due to the proximity of the airstrip (Davidson et al. 1989:18)

Reassessment of the site in 2016 revealed little damage beyond that originally recorded, although the gidgee superstructure was less well-preserved than in 1989. On the hillslope, including in and around some of the stone hut structures, is a range of artefacts that includes silcrete flakes and cores, freshwater mussel shells (Velesunio ambiguus), fragments from edge-ground axes made from non-local igneous rock, rifle cartridge cases, fragments of glass, metal belt buckles and metal tins. There is no apparent difference between material associated with the circular stone hut structures and those that are more rectangular in plan.

It is worth noting that these are not the only stone hut structures on Marion Downs Station. During the 1989 investigation several other similar clusters of stone hut structures were also located, as well as further west on Glenormiston Station, though time constraints precluded any of these being recorded. Robert Jansen (pers. comm., 2016), the current manager of Marion Downs Station, has also reported seeing additional stone hut clusters along the Georgina River from the air whilst mustering.

\section{Discussion}

Memmott (2012:2) noted that the form of built structures in Australia was dependent on a range of factors, including 'the prevailing weather, availability of local raw materials, planned purpose and length of stay, and size and composition of the group to be accommodated'.

In the Marion Downs case study, if indeed roofed as we suspect they originally were, these stone hut structures would have provided substantial protection for small groups of people from heavy summer rains, particularly since there are few rockshelters in the region that could have been used as an alternative means of protection. In this sense, it is also important to consider the prevailing wind direction. The generally flat or low undulating local landscape is conducive to a strong wind regime from the south and southwest, so it is not surprising to find that the openings in the structures are generally to the north. As such, they would have afforded useful shelter, especially during cold winter nights.

The boulder-strewn hillslopes of the local landscape afford a wealth of easily obtained building materials. Without clearing the hillslope it would be nearly impossible to have a comfortable night's sleep in the vicinity, and moving further down the hillslope to the river flat would require people to contend with boggy ground during wet months.

One possibility is that the stone structures we recorded were not part of 'huts' per se, but simply the result of people moving boulders to create clear areas on which to sit and/or sleep. However, we consider it unlikely that expedient behaviour of that nature would have produced such consistently shaped and sized structures, with openings all facing in the same direction. It seems much more likely that these structures were purposefully built to a distinct pattern, and were most likely domestic in nature (i.e. the bases of 'hut structures').

The Marion Downs stone hut structures bear resemblance to purported domestic stone structures from elsewhere in Australia, a summary of the salient features of which is presented in Table 1. For example, in southwest Victoria on the now drained former swamp area near Lake Condah is an extensive water management system of channel ponds, weirs and traps (Builth 1996, 2000, 2002, 2004; Builth et al. 2008; McNiven et al. 2012), associated with culturally modified trees and stone walled 'house sites' (e.g. Clark 1990; Clarke 1991, 1994; Coutts et al. 1978; Lane and Fullagar 1980; Lourandos 1987; Richards 2011; Wesson 1981; Worsnop 1897). The stone hut structures (126 of which were recorded in 1991) are semi-circular, c-shaped, or u-shaped, can occur in isolation but are generally in clusters of $2-16$, and were constructed using the abundant basalt cobbles locally available (Clarke 1994). They were noted by an early writer as always occurring in open places where timber was scarce (Lane 2009:14). Determining the age of any of the Lake Condah stone structures has been challenging, and most attention has been paid to the water management system rather than the huts themselves, with their age placed at midto-late Holocene (e.g. Builth et al. 2008; Head 1989; Lourandos 1980; Williams 1985, 1987, 1988). Recent excavations and dating of the Muldoons Trap Complex has demonstrated initial activity between 5400-6600 cal BP, followed by little or no activity at the site until a more recent period of redevelopment and elaboration in the last 800 years (McNiven et al. 2012, 2015). While these dates do not address the issue of the age of the stone hut structures directly, given the close association between various components of the system, the Muldoons Trap Complex may also approximate the age of the huts.

Blundell (1975:156) and later O'Connor (1987, 1999:113-117) described stone structures in open contexts on High Cliffy Island in the west Kimberley. These comprise circular structures with a usable internal area up to $3 \mathrm{~m} \times 3 \mathrm{~m}$, with 1m-high walls. O'Connor (1987:37) posited that these, too, were probably wet season structures constructed in an area with few natural rockshelters. Attempts to date them were unsuccessful, though a fragment of baler shell on the surface inside one structure returned an age of $370 \pm 50 \mathrm{BP}$ (Wk-1095) (O'Connor 1987:34). The tabular nature of the local sandstone means that the structures on High Cliffy Island have quite obvious coursing and are much 'neater' than the Marion Downs structures (since the rounded nature of the local Georgina Basin boulders does not lend itself to wellstructured walls). Aboriginal people working with Blundell (1975:156) informed her that the structures were primarily windbreaks that had originally been roofed with sheets of paperbark brought over from the mainland. More recently, O'Connor et al. (2007) reported a single stone 'hut' on Rankin Island, not far from High Cliffy, also constructed of tabular sandstone (though its walls had collapsed). They described this as being very similar to the High Cliffy huts, although further information was not provided.

Most recently McDonald and Berry (2017) reported the documentation and excavation of stone hut structures on Rosemary Island in Murujuga (Dampier Archipelago) off the Pilbara coastline. Forming a series of conjoined structures, the largest of the Rosemary Island structures measures $8.7 \mathrm{~m} \mathrm{x}$ 
Table 1. Summary of reported domestic stone hut structures from around Australia.

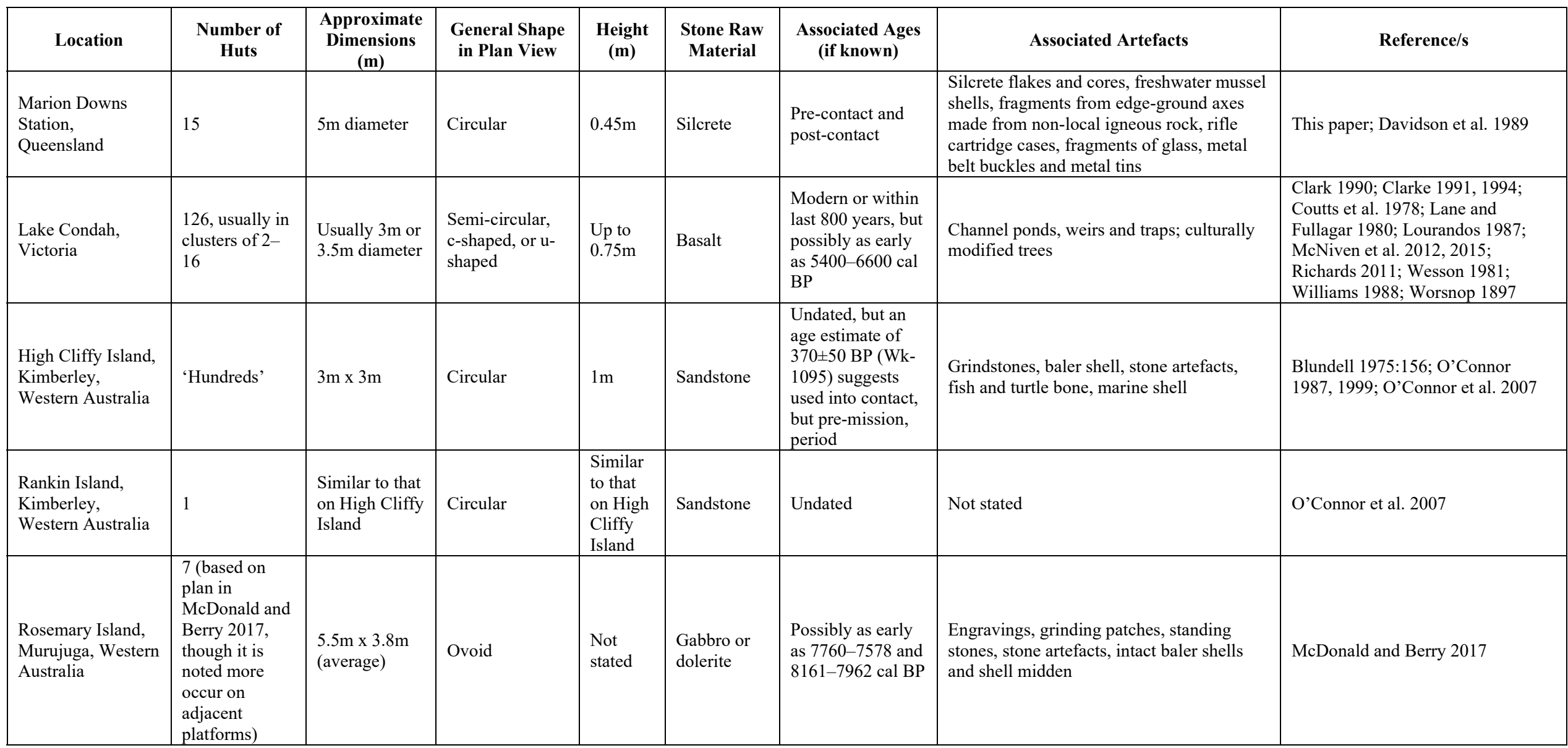


$5 \mathrm{~m}$, though the average size is $5.5 \mathrm{~m} \times 3.8 \mathrm{~m}$. These structures are also associated with engravings, grinding patches, standing stones, stone artefacts, intact baler shells and shell midden, leading the authors to interpret them as likely habitation dwellings. Excavation of midden deposit inside the walls of one of the structures produced age determinations of 7760-7578 and 8161-7962 cal BP, potentially making them the oldest known domestic stone structures in Australia (McDonald and Berry 2017). Insufficient information is presented by McDonald and Berry (2017) to be confident that the dated shell is genuinely associated with use of the structures. It is possible that the shell was deposited 9000 years ago, and at a time much more recently the stone structures were built on top of that deposit. The only way to assess this possibility would be to determine whether the shell material underlies the walls themselves; unfortunately, the excavations undertaken at Rosemary Island were neither extensive nor extended under the walls and so this cannot be determined.

Memmott (2007:4) suggested there were four periods in Aboriginal architecture, the first being 'the classical Aboriginal ethno-architecture practised prior to the arrival of the colonists', and the second being 'acculturated ethnoarchitecture of the 19th and 20th centuries'. The Marion Downs Station site was described as a contact site by Rowlands and Rowlands (1978). Their assessment was based on the presence of contact period surface artefacts; no excavations were conducted, and absolute dating of the abundant surface mussel shell was not undertaken. While it is possible the stone hut structures could date to some time after contact with Europeans and their more complex building methods, Roth (1897:106) specifically mentioned that the local Aboriginal response to contact - which brought with it the availability of cattle hides, clothing and blankets - was to invest less effort in housing, leading to the 'gradual and marked disappearance' of the semi-subterranean houses they had previously built. Roth (1897) made no mention of stonewalled structures. Given their apparent prevalence in the region south of Boulia, the question of their dating relative to European contact is a matter of some interest. The Marion Downs Station stone hut structures seem to represent more, not less, effort, and so it seems unlikely the origin of the practice is post-contact. Roth, it should be noted, does not seem to have travelled south of Boulia to any great extent, and, other than his visits to Glenormiston, seems likely to have travelled by coach (Davidson 2008).

We argue that the stone hut structures recorded on Marion Downs Station are not European in origin. The majority of structures built using European techniques of dry stonewalling in Australia conform to a repeated pattern of design, summarised by Radford (2001) as including:

- the use of foundation stones to 'anchor' the wall to the ground;

- the use of 'face stones' (or 'skins') with occasional 'through stones' to tie the two sides of the wall together;

- bridged joins (meaning that each course of stones is offset from that underlying it so that the joins between rocks do not line up vertically and create weaknesses in the structure);

- the use of 'pinning stones' placed under or between face stones to secure them;
- the use of small uneven stones ('hearting') placed in the centre of the wall to fill the gap between the face stones; and,

- the use of a course of 'coping-stones' at the top of the structure to help protect the wall from the elements.

The stone hut structures on Marion Downs Station generally do not contain any of these features. Foundation stones do not 'anchor' the walls to the ground and the walls do not have two sides or facing stones filled with hearting. Bridged joints appear occasionally but not systematically.

The fact that there are so many stone hut structures on Marion Downs Station further suggests they are not merely a post-contact phenomenon, otherwise we could assume that they would be much more limited in number. However, the presence of contact period artefacts on the surface leads us to agree with Rowlands and Rowlands (1978) that they were certainly used into the late nineteenth and likely early twentieth century. The fact that they are of a type not recorded by Roth may be significant, in that it suggests they were not in use at the time of his travels in the late nineteenth century.

In the event that excavation shows that the structures postdate the arrival of Europeans in the region, and maybe even the construction of a Native Mounted Police camp at Boulia (which comprised several rectangular stone-walled buildings), we could argue that they were built in response to the observations of European building. As such they would represent another instance of the entanglement of European and Aboriginal material culture that has been documented by Rowlands (2016) for artefacts from Boulia in the Queensland Museum's Roth collection.

\section{Conclusion}

Recent years have seen a growing appreciation of Aboriginal building techniques, highlighted by Memmott's (2007) seminal publication. The use of stone as a raw material for building seems to have occurred in many different places across the continent, though published sources about built structures are limited. This paper has documented the presence of what are almost certainly domestic stone hut structures in a region that affords few rockshelters for natural protection from the elements. These structures appear similar to those seen elsewhere in Australia in that they are a dry stone technique built of locally available, unmodified boulders easily transported by a single person and rarely display regular coursing. A key point to be made is the clear understanding that, around Australia, traditional Aboriginal stone walling was very different in nature to that of European dry stone walling techniques.

\section{Acknowledgements}

This research was supported under the Australian Research Council's Discovery Project titled 'The Archaeology of the Native Mounted Police' (project number DP160100307). It is based on fieldwork originally undertaken in 1989 by authors Davidson, Burke and Mitchell and funded by the Australian Heritage Commission. Pastoralists Bill and Rhonda Alexander, and Robert Jansen are thanked for their generosity in allowing us to carry out the work. We are grateful to Tom Sullivan (deceased), James Taylor, Keith Marshall and Harry Spencer for their insights and contributions. Thanks to the three referees for their comments, and to Sean Ulm for editorial feedback. 


\section{References}

Blundell, V. 1975 Change and Adaptation in the West Kimberley. Unpublished PhD thesis, Department of Anthropology, University of Wisconsin, Madison.

Builth, H. 1996 Lake Condah Revisited: Archaeological Constructions of a Cultural Landscape. Unpublished BA(Hons) thesis, Department of Aboriginal Studies, University of South Australia, Adelaide.

Builth, H. 2000 The connection between the Gunditjmara Aboriginal people and their environment: The case for complex hunter-gatherers in Australia. In G. Moore, J. Hunt and L. Trevillion (eds), Environment-Behaviour Research on the Pacific Rim, pp.197-212. Sydney: Faculty of Architecture, University of Sydney.

Builth, H. 2002 The Archaeology and Sociology of Gunditjmara: A Landscape Analysis from Southwest Victoria. Unpublished $\mathrm{PhD}$ thesis, Department of Archaeology, Flinders University, Adelaide.

Builth, H. 2004 Mt Eccles lava flow and the Gunditjmara connection: A landform for all seasons. Proceedings of the Royal Society of Victoria 116(1):163-182.

Builth, H., A.P. Kershaw, C. White, A. Roach, L. Hartney, M. McKenzie, T. Lewis and G. Jacobsen 2008 Environmental and cultural change on the Mt Eccles lava-flow landscapes of southwest Victoria, Australia. The Holocene 18(3):413-424. https://doi.org/10.1177/0959683607087931

Bureau of Meteorology (BoM) 2016 Climate Data Online (Marion Downs and Boulia Airport Weather Stations). Accessed online on 3 August 2016 from http://www.bom.gov.au/climate/data index.shtml.

Clark, I.D. 1990 The People of the Lake, Lake Condah, Victoria, Australia: An Information Manual. Unpublished report by Koorie Tourism Unit, Victorian Tourism Commission.

Clarke, A. 1991 Lake Condah Project Aboriginal Archaeology Resource Inventory. Victoria Archaeological Survey Occasional Report 36. Melbourne: Department of Conservation and Environment.

Clarke, A. 1994 Romancing the stones: The cultural construction of an archaeological landscape in the Western District of Victoria. Archaeology in Oceania 29(1):1-15.

Coutts, P.J.F., R.K. Frank and P. Hughes 1978 Aboriginal Engineers of the Western District. Victoria Records of the Victorian Archaeological Survey 7. Melbourne: Ministry for Conservation.

Davidson, I. 2008 Ethnological studies and archaeology of north west central Queensland. In R. McDougall and I. Davidson (eds), The Roth Family, Anthropology and Colonial Administration, pp.121-132. Walnut Creek, CA: Left Coast Press.

Davidson, I., H. Burke and S. Mitchell 1989 Archaeological Sites in Northwest Central Queensland. Unpublished report to Australian Heritage Commission, Canberra.

Head, L. 1989 Using palaeoecology to date Aboriginal fishtraps at Lake Condah, Victoria. Archaeology in Oceania 24(3):110-115. https://doi.org/10.1002/j.1834-4453.1989.tb00220.x

Lane, L. and R.L.K. Fullagar 1980 Previously unrecorded Aboriginal stone alignments in Victoria. Records of the Victorian Archaeological Survey 10:134-151.

Lane, S. 2009 Aboriginal Stone Structures in Southwestern Victoria. Unpublished report to Aboriginal Affairs Victoria, Melbourne.

Lewis, D. 1988 Hawk hunting hides in the Victoria River District. Australian Aboriginal Studies 2:74-78.

Lourandos, H. 1980 Change or stability?: Hydraulics, huntergatherers and population in temperate Australia. World Archaeology 11:245-264. https://doi.org/10.1080/00438243.1980.9979765
Lourandos, H. 1987 Swamp managers of southwestern Victoria. In D.J. Mulvaney and J.P. White (eds), Australians to 1788, pp.292307. Broadway: Fairfax, Syme and Weldon.

McDonald, J. and M. Berry 2017 Murujuga, northwestern Australia: When arid hunter-gatherers became coastal foragers. Journal of Island and Coastal Archaeology 12(1):24-43. https://doi.org $\underline{\text { 10.1080/15564894.2015.1125971 }}$

McNiven, I.J., J. Crouch, T. Richards, N. Dolby, G. Jacobsen and Gunditj Mirring Traditional Owners Aboriginal Corporation 2012 Dating Aboriginal stone-walled fishtraps at Lake Condah, southeast Australia. Journal of Archaeological Science 39(2):268-286. https://doi.org/10.1016/j.jas.2011.09.007

McNiven, I.J., J. Crouch, T. Richards, K. Sniderman, N. Dolby and Gunditj Mirring Traditional Owners Aboriginal Corporation 2015 Phased redevelopment of an ancient Gunditjmara fish trap over the past 800 years: Muldoons Trap Complex, Lake Condah, southwestern Victoria. Australian Archaeology 81:44-58. https://doi.org/10.1080/03122417.2015.11682064

Memmott, P. 2007 Gunyah, Goondie and Wurley: The Aboriginal Architecture of Australia. St Lucia, QLD: University of Queensland Press.

Memmott, P. 2012 Aboriginal architecture. In J. Willis and P. Goad (eds), Encyclopedia of Australian Architecture, pp.1-4. Cambridge: Cambridge University Press.

Mulvaney, K. 1993 Hunting with hides: Ethnohistorical reflections on Victoria River stone structures. Records of the South Australian Museum 26(2):111-120.

O'Connor, S. 1987 The stone house structure of High Cliffy Island, northwest Kimberley, Western Australia. Australian Archaeology 25:30-39.

O'Connor, S. 1999 30,000 Years of Aboriginal Occupation: Kimberley, North West Australia. Terra Australis 14. Canberra: Department of Archaeology and Natural History and the Centre for Archaeological Research, The Australian National University.

O'Connor, S., L. Zell and A. Barham 2007 Stone constructions on Rankin Island, Kimberley, Western Australia. Australian Archaeology 64:15-22. https://doi.org/10.1080/03122417.2007 $\underline{.11681845}$

Radford, A. 2001 A Guide to Dry Stone Walling. Marlborough: The Crowood Press.

Richards, T. 2011 A late nineteenth-century map of an Australian Aboriginal fishery at Lake Condah. Australian Aboriginal Studies 2:64-87.

Roth, W.E. 1897 Ethnological Studies among the North-WestCentral Queensland Aborigines. Brisbane: Government Printer.

Rowlands, R.J. and M.J. Rowlands 1978 Aboriginal Stone Arrangements. Report on Field Work in Western New South Wales and Queensland: August-October 1978. Unpublished report to Australian Institute of Aboriginal Studies, Canberra.

Rowlands, S.C. 2016 Frontier Shores: Collection, Entanglement, and the Manufacture of Identity in Oceania. New York: Bard Graduate Centre.

Wallis, L.A. and J. Matthews 2016 Built structures in rockshelters of the Pilbara, Western Australia. Records of the Western Australian Museum 31:1-26. https://doi.org/10.18195/issn.0312-3162.31(1) .2016.001-026

Wesson, J. 1981 Excavations of Stone Structures in the Condah Area, Western Victoria. Unpublished MA preliminary thesis, La Trobe University, Bundoora.

Williams, E. 1985 Wet Underfoot? Earth Mound Sites and the Recent Prehistory of Southwestern Victoria. Unpublished PhD thesis, Australian National University, Canberra. 
Williams, E. 1987 Complex hunter-gatherers: A view from Australia. Antiquity 61:310-321. https://doi.org/10.1017 /S0003598X00052182

Williams, E. 1988 Complex Hunter-Gatherers: A Late Holocene Example from Temperate Australia. BAR International Series 423. Oxford: Archaeopress.

Wilson, P.R. 1990 Topography, geomorphology, geology and hydrology. In P.R. Wilson, R.W. Purdie and C.R. Ahern (eds), Western Arid Region Land Use Study, pp.3-8. Part VI. Technical Bulletin 28. Brisbane: Division of Land Utilisation, Department of Primary Industries.
Worsnop, T. 1897 The Prehistoric Arts, Manufactures, Works, Weapons, etc, of the Aborigines of Australia. Melbourne: C.E. Bristow, Government Printer.

Citation: Wallis, L.A., I. Davidson, H. Burke, S. Mitchell, B. Barker, L. Hatte, N. Cole and K.M. Lowe 2017 Aboriginal stone huts from the Georgina River, southwest Queensland. Queensland Archaeological Research 20:1-8. https://doi.org /10.25120/qar.17.2017.3584 